\title{
MENEROPONG SISTEM PRODUKSI DALAM EKONOMI KONVENSIONAL
}

\author{
Moh. Subhan \\ STAI Miftahul Ulum Pamekasan
}

\begin{abstract}
The production is an activity related to the way how INPUT can be used to generate a product (OUTPUT). Production, distribution and consumption is a series of interrelated economic activities. All three are influence each other, but the production is the base of economic activity. The production is human activity to produce goods and services which are then exploited by consumers. Production activities in perspective of Economics of Islam is not only oriented to maximize profits (maximizing of profit) consequential matter, regardless of the existing rules, as conventional economic paradigms, but more of that production in Islam is more oriented on expression of obedience to God's commands, namely to provide for the needs of both spiritual as well as material in order to create maslahah maximizer in the form of benefits and blessings can sustain existence as well as the height degree of human beings. Production factors include; capital (Capital/Ra'sul maal), labor (Labor/' charity), natural resources (Resouches/ "Ardh.).
\end{abstract}

Keyword: The Sistem of Production, Convensional economic

\section{Pendahuluan}

Produksi adalah kegiatan manusia untuk menghasilkan barang dan jasa yang bermanfaat bagi umat manusia. ${ }^{1}$ Secara teknis, produksi adalah proses mentransformasi input menjadi output. Produksi dalam pandangan ilmu ekonomi mencakup tujuan kegiatan yang menghasilkan output serta karakterkarakter yang melekat padanya. Terdapat beberapa pengertian produksi yang disampaikan oleh pakar ekonomi muslim. ${ }^{2}$ Meskipun definisi-definisi tersebut

\footnotetext{
${ }^{1}$ P3EI UII, Ekonomi Islam, Jakarta, PT. RajaGrafindo Persada, 2008, h. 231

${ }^{2}$ Dr. Muhammad Rawwas Qalabji memberikan padanan kata "produksi” dalam bahasa Arab dengan kata al-intaj yang secara harfiyah dimaknai dengan ijadu sil'atin (mewujudkan atau mengadakan sesuatu) atau khidmatu mu'ayyanatin bi istikhdami murayyajin min 'anashir al-intaj dhamina itharu zamanin muhaddadin (melakukan pelayanan jasa yang jelas dengan menuntut adanya bantuan pengabungan unsur-unsur produksi yang terbingkai dalam waktu yang terbatas). Manzer Kahf, produksi adalah usaha manusia untuk memperbaiki fisik material dan moralitas dalam rangka mencapai kebahagiaan hidup di dunia dan akhirat. Muhammad Najetullah Siddiqi mendefinisikan produksi dengan upaya menyediakan barang dan jasa dengan memperhatikan nilai keadilan dan kemaslahatan bagi masyarakat.
} 
mengelaborasi dari perspektif yang berbeda-beda, tetapi secara substansinya sama, bahwa produksi merupakan upaya mengalokasikan dan mengelola sumber daya menjadi output (barang) dalam rangka meningkatkan kemaslahatan bagi manusia.

Aktivitas produksi sepenuhnya harus sejalan dan beriringan dengan kegiatan konsumsi. Mengapa demikian? Sebab, jika tidak, maka aktivitas ekonomi tidak akan berhasil mencapai tujuan yang diharapkan. Aktivitas produksi masih dilakukan oleh orang perorangan/individu, disaat kebutuhan manusia masih sedikit dan sederhana, tetapi pada saat kebutuhan kebutuhan manusia sudah beragam dan sumber daya yang ada terbatas, maka kegiatan produksi sudah tidak mungkin dilakukan oleh orang perorang, tetapi sudah dilakukan oleh sekelompok orang atau perusahaan, dan pada saat ini, hampir tidak ada manusia yang mampu mencukupi kebutuhannya sendiri.

\section{Orientasi Produksi Ekonomi Konvensional Vs Ekonomi Islam}

Pemahaman terhadap konsep produksi selama ini masih bersifat pragmatis dan masih materiel oriented (materi sebagai acuan utamanya) serta peniadaan pada aspek produksi yang berorientasi jangka panjang. Pijakan utama yang dibangun ekonomi konvensional dalam berproduksi adalah memaksimalkan keuntungan (maximizing of profit) dan menekan seminimal mungkin biaya (minimizing of cost). Strategi, konsep, dan teknik berproduksi semuanya diarahkan untuk mencapai keuntungan maksimum, baik dalam jangka pendek (short run profit) maupun jangka panjang (long run profit). Milton Friedman seorang peraih "nobel laureate" di bidang ekonomi menyatakan bahwa satusatunya fungsi dunia bisnis adalah melakukan aktivitas yang ditujukan untuk meningkatkan keuntungan (provit), sesuai dengan aturan main (rule of the game) yang ada. Upaya maksimalkan keuntungan tersebut, terkadang membuat sistem ekonomi konvensional sangat mendewakan produktivitas dan efesiensi pada saat berproduksi, sehingga tidak jarang sikap ini menyebabkan produsen mengabaikan etika dan tanggung jawab sosialnya, meskipun mungkin tidak melakukan pelanggaran hukum formal. ${ }^{3}$ Sebagai contoh kasus dalam skala internasional adalah, adanya impor kayu dalam jumlah besar oleh negara-negara maju dari hasil illegal loging dari negara-negera sedang berkembang seperti Brazil dan Indonesia. Illegal loging telah memberikan support pada perekonomian negara-negara maju, karena dengan menggunakan kayu hasil illegal logingmereka dapat menekan biaya produksi dalam jumlah yang sangat signifikan. Tuntutan dan sekaligus protes yang diajukan oleh negara-negara penghasil kayu terbesar

\footnotetext{
${ }^{3}$ Murasa Sarkaniputra, Adil dan Ihsan dalam Perspektif Ekonomi Islam: Implementasi Mantik Rasa dalam Model Konfigurasi Teknologi al-Ghazali-as-Syaribi-Leontief-Sraffa, draft artikel untuk Jurnal al-Iqtishadiyyah, h. 2
} 
dunia seperti Brazil dan Indonesia kepada negara-negara yang tergabung dalam G-8 agar membuat legislasi (aturan hukum resmi) yang melarang warganya agar tidak mengimpor kayu hasil illega loging tidak pernah direspon secara positip. Di sini terlihat jelas adanya upaya sistematis dari negara-negara maju yang tergabug dalam G-8 untuk terus melestarikan impor kayu hasil illegal loging tersebut.

Gambaran kasus di atas menunjukkan bahwa motivasi produsen untuk memaksimumkan keuntungan seringkali merugikan pihak lain, dalam hal ini adalah negara penghasil kayu, seperti Brazil dan Indonesia.

Disamping itu, ekonomi konvensional tidak mempermasalahkan apakah produknya bermanfaat bagi masyarakat umum atau hanya dikonsumsi oleh segelintir masyarakat kaya saja. Hal tersebut tidak menjadi pertimbangan dalam berproduksi, yang penting produk tersebut mendatangkan keuntungan dan produksi bisa efesien.

Paradigma ekonomi konvensional di atas berbeda dengan paradigma yang dibangun oleh ekonomi Islam, dimana produksi dalam ekonomi Islam menjangkau makna yang lebih luas. Produksi tidak hanya pencapaian aspek yang bersifat materi-keduniaan (provit oriented) saja, tetapi produksi menembus batas dimensi yang bersifat rohani-keakhiratan sebagai upaya untuk mencapai maslabah dan falab. ${ }^{4}$ Sehingga dalam melakukan produksi yang dijadikan standart utamanya adalah maslabah maximer dengan nilai manfaat (utility) yang diambil dari hasil produksi yang halal serta tidak membahayakan diri sendiri maupun sekelompok masyarakat. ${ }^{5}$ Dengan demikian, produksi dalam ekonomi Islam tidak hanya menyandarkan pada permintaan pasar (demand market) untuk memperoleh keuntungan dalam jumlah besar, melainkan juga mempertimbangkan kemaslahatan. ${ }^{6}$ Sehingga keuntungan (provit) yang diperoleh seimbang dengan modal atau usaha yang dilakukan. Sebagaimana dinyatakan dalam surat an-Najm; 39. Yang artinya:

Dan babwasanya seorang manusia tiada memperoleh selain apa yang Telah diusabakannya,

Lebih jauh, Al-Qur'an menekankan bahwa memproduksi suatu barang harus mempunyai hubungan dengan kebutuhan dan kelayakan hidup manusia. Sehingga memproduksi barang secara berlebihan dan melanggar aturan syara'

\footnotetext{
${ }^{4}$ Maslahab terdiri dari dua komponen; manfaat (fisik dan non fisik) dan berkah. Dalam konteks produsen/perusahaan yang berorientasi pada profit, maka manfaat dapat berupa keuntungan material. Keuntungan ini bisa dipergunakan untuk maslahah lainnya yang bersifat non fisik; pengembangan intelektual manusia/tenaga kerja. Falah kemuliaan dan kemenangan dalam kehidupan.

${ }^{5}$ Abdurrahman Yusro Ahmad, Muqaddimah fi Ilm al-Iqtishad al-Islamiy, Iskandariyah, 1988, h. 39

${ }^{6}$ MA Manan, Teori dan Praktek Ekonomi Islam, Terj. M. Nastangin, Dana Bhakti Wakaf, Yogyakarta, 1997. Lihat juga M.M. Metwally Teori dan Praktek Ekonomi Islam,.........
} 
dilarang oleh Islam, dan perbuatan yang berlebihan (mubadzir dan israf) dibenci oleh agama.

Mengacu pada pemikiran as-Syatibi, bahwa kegiatan produksi harus disandarkan pada upaya untuk memenuhi kebutuhan dasar manusia (basic need) yang mencakup lima hal, yaitu terjaganya kehidupan beragama ( $h i f d z u l$ ad-din), terpeliharanya jiwa (bifd₹ul an-nafs), terjaminnya berkreasi dan berfikir (bifd₹ul al'aq), terpenuhinya kebutuhan materi (bifdzul al-mal), dan tercapainya keberlangsungan meneruskan keturunan (bifdzul an-nas). Maka orientasi yang dibangun dalam melakukan produksi adalah tindakan yang seharusnya dilakukan oleh setiap pelaku ekonomi muslim dalam mengarahkan kegiatan produksinya untuk memenuhi kebutuhan dasar manusia yang lima tersebut.

Dr. Abdurrahman Yusro Ahmad dalam bukunya Muqaddimah fi $\mathrm{Tlm}$ alIqtishad al-Islamiy menjelaskan bahwa dalam melakukan proses produksi yang dijadikan ukuran utamanya adalah nilai manfaat (utility) yang diambil dari hasil produksi tersebut. ${ }^{8}$ Produksi dalam pandangannya harus mengacu pada nilai utility dan dalam bingkai 'balal serta tidak membahayakan bagi diri seseorang ataupun sekelompok masyarakat.

Sebuah perusahaan harus mempunyai nilai kepedulian sosial terhadap masyarakat sekelilingnya. Perubahan yang terjadi di luar lingkungan perusahaan, akan mempengaruhi kinerja perusahaan. Dengan demikian perusahaan akan tumbuh dengan baik, apabila lingkungan yang ada di sekitarnya mengakui keberadaan dan memberikan dukungan positip terhadap pelaksanaan kerja perusahaan. Upaya yang dilakukan antara lain melalui menciptakan keserasian hubungan perusahaan dan masyarakat sekitarnya (Corporate social responsibility) dengan mengalokasikan sebagian dana perusahaan sebesar 1,5\% sampai dengan $3 \%$ dari provit perusahaan untuk kepentingan sosial.

Produktivitas harus sejalan dengan terpeliharanya keadilan bagi semua orang. Setiap komponen masyarakat harus dipacu untuk menghasilkan sesuatu, sesuai dengan kemampuan dan bidangnya. Semua itu harus ada jaminan keamanan serta keadilan bagi setiap orang dan memberikan sanksi yang tegas bagi perilaku yang kontraproduktif.'

\section{Faktor dan Tujuan Produksi}

Kegiatan produksi membutuhkan berbagai jenis sumber daya ekonomi yang disebut input atau faktor produksi. Faktor produksi adalah segala hal yang

\footnotetext{
${ }^{7}$ Abu Ishaq as-Syatibi, al-Muwafaqat fi Ushul al-Ahkam, (Beirut: Dar al-Fikr, 1341 H), Juz II.

${ }^{8}$ Abdurrahman Yusro Ahmad, Muqaddimah fi Ilm ..., h. 39

${ }^{9}$ Mustafa Edwin Nasution, Ed all, Pengenalan Eksklusif Ekonomi Islam, Fajar Interpratama Offset, Jakarta, 2006, h. 117
} 
menjadi masukan (input) secara langsung maupun tidak langsung dalam proses produksi.

Tidak ada kesepakatan yang bulat di antara para pakar ekonomi tentang faktor produksi. ${ }^{10}$ Perbedaan klasifikasi faktor produksi ini dilatarbelakangi oleh banyak faktor, misalnya ketidak seragaman tentang definisi, karakteristik, maupun peran dari masing-masing faktor produksi dalam menghasilkan output (produk). Menurut Muhammad Rawwas Qalahji, dalam kitabnya "Mababis fi alIqtishad al-Islamiy min Usbulibi al-Fiqhiyyah", menyebutkan bahwa faktor produksi ada tiga, pertama, modal. Modal dalam sistem ekonomi Islam harus bebas dari riba. Islam menganjurkan pertambahan internal dalam investasi sebagai ganti simpanan dan mengajarkan adanya perputaran harta agar dapat menjadi alat produksi yang berguna. Produksi yang menggunakan modal finansial dapat berupa; syirkah/patnership dan mudlarabah. ${ }^{12}$ Dalam syirkah masing-masing pihak memberikan kontribusi dalam permodalan, di mana mereka bersepakat untuk melakukan loss-profit sharing. Dalam penentuan nisbah bisa berdasarkan nisbah kontribusi modal atau berdasar pada kesepakatan. Kerugian akan ditanggung bersama berdasarkan nisbah kontribusi modal. ${ }^{13}$

Kedua, Tenaga kerja. Dalam hal ini tenaga kerja adalah profesi dan perbuatan, sehingga pekerja adalah siapapun yang mengendalikan persoalanpersoalan orang lain yang berkaitan dengan harta, kepemilikan, dan aktivitas yang dilakukan. Islam memandang tenaga kerja sebagai faktor produksi yang utama (main input) dan memposisikan manusia pada harkat yang mulia. Oleh karena itu, aktivitas produksi yang bertentangan dengan harkat kemanusiaan dapat dikatakan bertentangan dengan ajaran Islam. Sementara dalam pandangan ekonomi konvensional, tenaga kerja dan kapital/modal memiliki kedudukan

${ }^{10}$ Menurut Abu Saud, Faktor produksi ada 4 sebagaimana pengklasifikasian ekonomi konvensional; tanah, tenaga kerja, modal dan organisasi, DR. Sa'ad Ibrahim Saleh, faktor produksi terdiri dari tiga komponen, yaitu: Bekerja, modal dan taqwa, Dr. Araby, faktor produksi hanya 2, yaitu modal dan bekerja.

${ }^{11}$ Secara bahasa bermakna riyadah/addition (tambahan), pertumbuhan (growth), sedangkan menurut makna istilah, riba bermakna pengambilan tambahan darai harta pokok atau modal secara batil (wrongful deveouring of property).

${ }^{12}$ Abi Muhammad Abdullah ibn Ahmad ibn Qudamah, al Mughny, Riyadl, Maktabah al Jumhuriyah al Arabiyah, tt, Juz 5, h. 22

${ }^{13}$ Pendapat pertama (nisbah berdasarkan nisbah kontribusi modal) dianut oleh madzhab Syafi'I dan Maliki. Misalnya dua orang yang melakukan musyarakah menyetor modal masingmasing $50 \%$, maka nisbah bagi hasilnya 50:50. Sedangkan pendapat kedua (berdasar kesepakatan) dianut oleh madzhan Hanafi dan Hanbali. Nisbah bagi hasil tidak semata-mata ditentukan berdasarkan porsi masing-masing dalam permodalan, tetapi atas pertimbangan kontribusi dalam organisasi dan kewirausahaan. Dalam hal ini dapat saja seseorang mendapatkan porsi bagi hasil yang lebih besar dari porsi kontribusi dalam permodalan karena memiliki kontribusi yang lebih besar dalam organisasi dan kewirausahaan. Demikian pula sebaliknya. 
yang setara, dimana keduanya adalah substitusi sempurna. Penggunaan tenaga kerja sebagaimana pengunaan modal, dapat sepenuhnya saling menggantikan berdasarkan pertimbangan efisiensi dan produktivitas. Jika menggunakan tehnologi padat kapital lebih murah daripda tehnologi tenaga kerja, maka produsen akan memilih yang pertama, dan demikian pula sebaliknya. Dalam dunia nyata, implementasi konsepsi substitusi ini telah menimbulkan berbagai persoalan ekonomi yang kompleks. Eksploitasi upah buruh dengan sistem outsorsing, PHK (pemutusan hubungan kerja), dan berbagai bentuk debumanisasi lainnya.

Ketiga, Sumber Daya Alam. Islam sangat menaruh perhatian terhadap realita hidup dan kehidupan manusia yang tidak terlepas dari alam dan lingkungannya, karena hal tersebut merupakan hubungan mutualisme dalam tatanan keseimbangan alam dan kehidupannya (Balancing Ecosystem). Sumber daya alam terbagi dua, yaitu Sumber daya alam yang tidak dapat diperbarui (unrenewable) dan sumber daya alam yang dapat diperbarui (renewable). Keanekaragaman hayati termasuk di dalam sumber daya alam yang dapat diperbaharui. Potensi sumber daya alam hayati tersebut bervariasi, tergantung dari letak suatu kawasan dan kondisinya. Pengertian istilah sumber daya alam cukup luas, yakni mencakup sumber daya alam hayati, tumbuhan, hewan dan bentang alam (landscape).

Sedangkan tujuan produksi menurut Islam adalah menyediakan barang dan jasa yang bersifat material dan spiritual untuk memberikan maslahah maksimum bagi konsumen. Secara lebih spesifik bahwa tujuan kegiatan produksi adalah meningkatkan kemaslahatan yang dapat terwujud dalam beberapa bentuk, yaitu: ${ }^{14}$

Pertama, pemenuhan kebutuhan manusia pada takaran moderat. Tujuan produksi sebagaimana tersebut akan menimbulkan dua implikasi, yaitu 1) produsen hanya akan memproduksi barang dan jasa yang menjadi kebutuhan (needs) meskipun belum tentu merupakan keinginan (wants) konsumen. Barang dan jasa yang dihasilkan harus memiliki manfaat riil bagi kehidupan yang islami, bukan sekedar memberikan kepuasan maksimum bagi konsumen. Sehingga prinsip costumer satisfaction (kepuasan pelanggan) dan given demand hipotesis (hipotesa pemenuhan permintaan) yang dijadikan pegangan oleh ekonomi konvensional tidak dapat diimplementasikan begitu saja. ${ }^{15}$ 2), kuantitas produksi

\footnotetext{
${ }^{14}$ M. Nejatullah Siddiqi, Economic Enterprice in Islam, Delhi, Markaz Makhtaba Islami, 1979, h. 11-34

${ }^{15}$ Pandangan ini menganggap bahwa permintaan pasar sebagai "given" di mana produsen yang berorinetasi pada keuntungan maksimum akan mengikuti segala permintaan pasar (demand market). Umpama; adanya permintaan pasar terhadap penyediaan minuman keras (sabu-sabu) walaupun ada indikasi akan menghasilkan keuntungan yang besar bagi produsen, maka hal itu tetap tidak boleh dilakukan produsen.
} 
tidak akan berlebihan, tetapi hanya sebatas kebutuhan yang wajar. Produksi barang dan jasa secara berlebihan tidak saja menimbulkan mis-alokasi sumber daya ekonomi dan kemubadziran, tetapi menyebabkan terkurasnya sumber ekonomi dengan cepat.

Kedua, Menemukan kebutuhan masyarakat dan pemenuhannya. Meskipun produksi hanya menyediakan sarana kebutuhan manusia, hal ini tidak berarti bahwa produsen hanya sekedar reaktif tehadap kebutuhan konsumen. Produsen harus kreatif, dan inovatif untuk menemukan berbagai jenis produk baru yang dibutuhkan oleh masyarakat. Sikap proaktif ini sangat penting, sebab terkadang konsumen juga tidak mengetahui apa yang sebenarnya dibutuhkan. ${ }^{16}$

Ketiga, menyiapkan persediaan barang dan jasa di masa yang akan datang. Sikap proaktif dan inovatif saja tidak cukup, harus dibarengi dengan adanya orientasi masa depan (future view). Hal ini berarti, bahwa dalam memproduksi barang dan jasa harus benar-benar bermanfaat bagi kehidupan masa sekarang dan masa mendatang, dengan adanya kesadaran bahwa sumber daya ekonomi, baik yang natural resources maupun yang non natural resources, tidak hanya diperuntukkan untuk manusia sekarang, tetapi juga untuk manusia yang akan datang. Orientasi ke depan ini akan memotivasi produsen untuk melakukan riset dan pengembangan (research and development) secara kontinyu guna menemukan berbagai jenis kebutuhan yang sesuai dengan tuntutan masa mendatang dengan tetap memperhatikan lingkungannya. Dengan konteks ini, maka produksi yang berwawasan lingkungan (green production) akan menjadi konsekwensi logis. Oleh karena itu ajaran Islam memberikan peringatan yang keras terhadap perilaku manusia yang melakukan ekploitasi sumber daya alam secara berlebihan demi mengejar kepuasaan tanpa memperhatikan lingkungan. Sebagaimana disebutkan dalam al Qur'an Surat al-A'raf; 56.

Implikasi dari aktivitas di atas adalah tersedianya kebutuhan bagi generasi mendatang secara memadai. Oleh karena itu, maka perilaku seperti eksplorasi gas dan minyak bumi secara berlebih-lebihan harus dihindari.

Ke-empat, sebagai pemenuhan sarana bagi kegiatan sosial dan beribadah kepada Allah. Tujuan produksi yang berorientasi pada pemenuhan sarana kegiatan sosial dan ibadah mempunyai implikasi yang sangat luas, selain tujuantujuan yang berorientasi sosial, produksi dalam Islam juga harus berorintasi spiritual. Oleh karena itu, maka tujuan produsen dalam menghasilkan sebuah produk harus sejalan dan sesuai dengan tujuan hidup seorang muslim. Islam tidak melarang mencari keuntungan melalui produksi dan kegiatan bisnis lain.

${ }^{16}$ Dalam teori perilaku konsumsi ekonomi konvensional diasumsikan bahwa konsumenlah yang lebih mengetahui terhadap apa yang diinginkannya sehingga produsen hanya merespon permintaan konsumen apa adanya. Dalam hal konsumsi hal ini tidak selamanya benar, sebab banyak konsumen yang tidak mengetahui adanya kebutuhan bagi dirinya sehingga harus ada pihak lain yang membantu menunjukkan akan kebutuhannya. 
Asalkan dilakukan dengan sungguh-sungguh. Tujuan ini membawa implikasi yang luas, sebab produksi tidak selalu menghasilkan keuntungan material, tetapi juga keuntungan yang bersofat in material.

\section{Produksi dengan Teknologi Konstan}

Konsep produksi yang sesuai dengan nilai Islam adalah suatu konsep yang menganggap bahwa teknologi berproduksi adalah sudah konstan, dalam arti bahwa teknologi yang digunakan adalah memanfaatkan sumber daya manusia yang ada sehingga mereka mampu meningkatkan harkat martabat kehidupannya. Selain itu, sebagai implikasi dari nilai amanah adalah dengan memakai sumber daya alam yang ada di lingkungannya (locality) secara bijak. Oleh karena itu, maka permasalahan produksi bukanlah mencari teknologi berproduksi sehingga memberikan keuntungan yang maksimum, melainkan mencari jenis out put dari berbagai kebutuhan manusia yang bisa diproduksi dengan teknologi yang sudah ada, sehingga menghasilkan sesuatu produk yang membawa maslahah bagi kehidupan manusia.

Sebagai ilustrasi, jika di suatu daerah banyak tenaga kerja, maka yang harus dilakukan oleh seorang produsen adalah bagaimana memanfaatkan tenaga kerja tersebut agar mereka bisa memperoleh pendapatan yang layak dalam rangka mempertahankan hidup dan kehidupannya sebagai makhluk Allah. Ada banyak alternatif yang bisa dilakukan, seperti memperkerjakan mereka di perkebunan, pertanian, kerajinan, industri, perdagangan, dan lainnya. Begitu juga ketika agen ekonomi Islam melihat banyak manusia yang menguasai tehnologi (keablian/skill), maka yang harus dilakukan adalah bagaimana memanfaatkan faktor produksi tersebut (skill) agar berdaya guna. Ada beberapa pilihan produk yang bisa dihasilkan oleh faktor produksi tersebut, mulai dari produk-produk yang berkualitas rendah sampai produk yang berkualitas tinggi.

\section{Kesimpulan}

Produksi dalam sistem ekonomi konvensional berorientasi pada memaksimalsasi keuntungan (maximizing of profit) dan meminimalisasi biaya (minimizing of cost), sementara ekonomi Islam kegiatan produksi dijadikan sebagai sarana untuk menciptakan barang/jasa, atau aktivitas untuk menjadikan barang/jasa lebih berdaya guna dengan prinsip syariah. Aktivitas produksi yang dilakukan oleh seorang muslim merupakan aktualisasi dari sifat taqwa kepada Allah swt. Sehingga prinsip, proses dan tujuan produksi selalu disandarkan pada nilai-nilai Islam.

Sehingga dalam melakukan produksi yang dijadikan standart utamanya adalah maslabah maximer dengan nilai manfaat (utility) yang diambil dari hasil produksi yang halal serta tidak membahayakan diri sendiri maupun sekelompok masyarakat. 
Dengan demikian, produksi dalam ekonomi Islam berbeda dengan ekonomi konvensional, di mana dalam produksi tidak hanya menyandarkan pada permintaan pasar (demand market) untuk memperoleh keuntungan dalam jumlah besar, melainkan juga mempertimbangkan kemaslahatan. Sehingga keuntungan (provit) yang diperoleh seimbang dengan modal atau usaha yang dilakukan.

\section{Daftar Pustaka}

Abi Muhammad Abdullah ibn Ahmad ibn Qudamah, al Mughny, Riyadl, Maktabah al Jumhuriyah al Arabiyah, tt,

Al Manawi, Faidl al Qadir Syarh Al Jami al Shaghir, 1391, Cet. 2

Abdul Husein, Abdullah at Thariq, Ekonomi Islam, Prinsip, Dasar dan Tujuan, dalam terjemahan, Magistra Insani Press, Yogyakarta, 2004

Depag, Al Qur'an dan Terjemabnya, 1997

Edwin, Mustafa Nasution, Pengenalan Ekslusif, Ekonomi Islam, Jakarta, Prenada Media Group, 2006

Ishaq, Abu as-Syatibi, al-Muwafaqat fi Ushul al-Abkam, (Beirut: Dar al-Fikr, 1341 H), Juz II.

Muhammad Rawwas Qalahji, Mabahis fi al-Iqtishad al-Islamiy min Ushulibi alFiqhiyyah, Beirut: Dar an-Nafes, 2000

M. Nejatullah Siddiqi, Economic Enterprice in Islam, Delhi, Markaz Makhtaba Islami, 1979

Mannan, Abdul M, Islamic Economics, Theory and Practice, Edisi terjemahan, Teori dan Praktek Ekonomi Islam Edt. Shonhaji, dkk.,

Monzer Kahf, The Islamic Economy: Analytical of The Functioning of The Islamic Economic System, Penerj: Machnun Husein, Ekonomi Islam: Telaah Analitik terhadap Fungsi Sistem Ekonomi Islam, Yogyakarta: Pustaka Pelajar, 1995

P3EI UII, Ekonomi Islam, UII Yogyakarta, Jakarta, PT RajaGrafindo Persada, 2008

Sarkaniputra, Murasa, Adil dan Ihsan dalam Perspektif Ekonomi Islam: Implementasi Mantik Rasa dalam Model Konfigurasi Teknologi al-Ghazali-as-Syaribi-Leontief -Sraffa, draft artikel untuk Jurnal al-Iqtishadiyyah

Yusro Ahmad, Abdurrahman, Muqaddimah fi Ilm al-Iqtishad al-Islamiy, Iskandariyah, 1988.

Zakky al Kafh, Abdullah, Ekonomi dalam Perspektif Islam, Pustaka Setia, Bandung, 2002 